UDC 633.16-145.71

Original research paper

doi: 10.5937/AASer1947061K

Acta Agriculturae Serbica, Vol. XXIV, 47(2019); 61-69

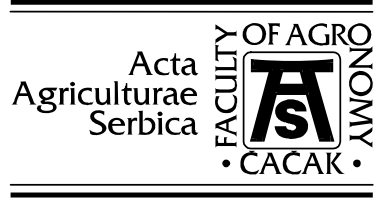

\title{
Variability in seed germination of barley cultivars (Hordeum vulgare L.) grown under different nitrogen application rates
}

\author{
Desimir Knežević ${ }^{1}$, Aleksandar Paunović ${ }^{2}$, Danijela Kondić ${ }^{3}$, Adriana \\ Radosavac $^{4}$, Artiona Laze ${ }^{5}$, Vlado Kovačević6 \\ ${ }^{1}$ University of Priština, Faculty of Agriculture, Kosovska Mitrovica-Lešak, \\ Kopaonička bb.,38219 Lešak, Kosovo and Metohija, Serbia \\ ${ }^{2}$ University of Kragujevac, Faculty of Agriculture, Cara Dušana 34, Čačak \\ 32000, Serbia \\ ${ }^{3}$ University of Banja Luka, Faculty of Agriculture, Bulevar Vojvode Petra \\ Bojovića, 1A, 78000 Banjaluka, Republika Srpska, Bosnia \& Herzegovina \\ ${ }^{4}$ University Business Academy in Novi Sad, Faculty of Applied Management, \\ Economics and Finance in Belgrade, Jevrejska 24, 11000 Belgrade, Serbia \\ ${ }^{5}$ Department of Chemistry, Faculty of Biotechnology and Food, Agriculture \\ University of Tirana, Koder - Kames, 1001, Tirana, Albania \\ ${ }^{6}$ J. J. Strossmayer University in Osijek, Faculty of Agrobiotechnical Sciences, \\ Vladimira Preloga 1, HR- 31000 Osijek, Croatia \\ ${ }^{7}$ Serbian Chamber of Commerce and Industry, Resavska15, Belgrade, Serbia \\ Corresponding author: deskoa@ptt.rs
}

\begin{abstract}
Variability in the percentage of seed germination was studied in four winter barley cultivars ('Jagodinac', 'Premium', 'NS 489' and 'NS 495'), grown under four nitrogen application rates (control $\mathrm{N}_{0}=0, \mathrm{~N}_{1}=20, \mathrm{~N}_{2}=40$ and $\mathrm{N}_{3}=60 \mathrm{~kg} \mathrm{ha}^{-1}$ ) during two years of the experiment. The experiment was carried out as a randomised block design in $5 \mathrm{~m}^{2}$ plots and with four replications. In both experimental years, the average seed germination was over $90.0 \%$ for all barley cultivars and in each nitrogen fertilisation treatment. The maximum seed germination percentage was $98.0 \%$ in 'Premium' in the second year in the treatment $\mathrm{N}_{3}=60 \mathrm{~kg} \mathrm{ha}^{-1}$, and minimum germination percentage
\end{abstract}


(90.1\%) was also recorded in 'Premium' 'in the first year of the experiment in the unfertilised control $\left(\mathrm{N}_{0}=0 \mathrm{~kg} \mathrm{ha}^{-1}\right)$. The obtained values of seed germination significantly differed among cultivars in the first and second year. Also, the average values of seed germination under four $\mathrm{N}$ fertilisation treatments were significantly different in both years. The average values for both years of the experiment were significantly different among cultivars and treatments. The values of seed germination for all cultivars increased with increasing nitrogen rates, suggesting that phenotypic variability in seed germination was affected by nitrogen fertilisation, which indicated a high value $(81.87 \%)$ of the component of phenotypic variance for seed germination.

Keywords: barley, variability, seed germination, nitrogen rate.

\section{Introduction}

The main task of barley breeders is to create cultivars which will achieve high yield, good quality and adaptation to abiotic and biotic stress factors. These plant traits are negatively correlated and influenced by morphological, anatomical, physiological and biochemical characteristics, which are determined by genetic and environmental factors, as well by the genotype/environment interaction (Coventry et al., 2003; Knežević et al., 2011). The reproduction of barley cultivars requires healthy and quality seeds with high percentage values of germination. Seed germination is a critical stage in the life cycle of plants, which involves proteases and where the proteolytic role has significant economic importance (Diaz-Mendoza et al., 2019). Seed germination affects the species abundance distribution of plant communities (Paunović et al, 2010). Variations in seed germinability can be related to different barley growing regions and environments due to environmental limitations, such as altitude, topography, soil quality and climate (Ranieri et al., 2012). A number of ecological and evolutionary factors can have implications for seed germination. Seed size is an important evolutionary trait which affects the reproductive success of many plant species, and is variable among species (Moles et al., 2006) and among cultivars within species (Paunović et al., 2010). Germination time, germination percentage and seedling vigour are directly influenced by seed size (Yanlong et al., 2007). A high percentage of seed germination affects the distribution and abundance of plant species across agroecological locations (Silveira et al., 2012). Research on seed germination in barley cultivars showed a more rapid germination of large seeds and a more rapid field emergence (Chastain et al., 1995). Also, seedlings produced from large seeds of winter barley emerged more rapidly and produced higher density stands than small seeds (Paunović et al., 2010).

Poor germination can be due to high humidity and high temperatures in the ripening stage, which can cause sprouting. Also, damage to the seed with a moisture content of over 13\% during handling (broken seed) and unsafe storage with a risk of fungal and insect infestation can cause a decline in percentage 
germination. Postharvest controls have combined chemical, physical and biological approaches, but only limited success has been achieved. Chlorine dioxide is often used to prevent seed infestation with microorganisms, pathogens and viruses. Soaking seeds with moderate $\mathrm{ClO}_{2}$ did not inhibit the germination of barley seeds and deform chlorophyll in barley leaves. On the contrary, it promoted the growth of barley roots, while treatments with high levels of $\mathrm{ClO}_{2}$ (1000 and $2000 \mathrm{mg} . \mathrm{L}^{-1}$ ) significantly decreased the germination percentage (Wang et al., 2019). An efficient way to preserve seed viability is storing seeds in conditions that cause minimum changes in biological characteristics. The development of morphological traits of plants is influenced by soil fertility, moisture and acidity, temperature, light and precipitation (Kondić et al., 2012). Spike traits are important in preserving both sprouting and the germination of seeds after harvest.

The production of vigorous quality seeds requires the use of scientific farming methods and crop control at all stages of plant growth until harvest and storage (Zečević et al., 2006). Also, depending on soil type, optimal mineral nutrition should be ensured (Koutna et al., 2003). There are differences in nitrogen absorption among cultivars (Kovačević et al., 2007; Paunović et al., 2007) which are adapted to variable environments. Growing barley cultivars at optimal nitrogen levels is suitable for the production of seeds with a high percentage of germination. Also, during the growing season, nitrogen leads to high seed germination and reduces weed seed emergence and density (Monaco et al., 2003). Nitrogen fertilisation increases barley yield and improves yield components (Madić et al., 2009; Knežević et al., 2015).

The objective of this research was to evaluate the effect of increasing rates of $\mathrm{N}$, applied during the growing season, on seed germination in four genetically divergent barley cultivars (Hordeum vulgare L.).

\section{Materials and methods}

Four winter barley cultivars ('Jagodinac', 'Premium', 'NS 489' and 'NS 495') were evaluated for seed germination during two years of the experiment which was performed in a randomised block design in $5 \mathrm{~m}^{2}$ plots and with 4 replications under four mineral fertilisation rates (control $\mathrm{N}_{0}=0, \mathrm{~N}_{1}=20, \mathrm{~N}_{2}=40$ and $\mathrm{N}_{3}=60 \mathrm{~kg} \mathrm{ha}^{-1}$ ). At full maturity, 80 plants (20 plants per replication) were sampled for analysis. Seed germination analysis was conducted after harvest in rolled paper towels placed in a germinator at $20^{\circ} \mathrm{C}(16$ hours $)$ and then at $30^{\circ} \mathrm{C}(8$ hours) according to the rules of the International Seed Testing Association (2010). The germinator was set to provide light during the high-temperature cycle ( 8 hours) and to remain dark during the low-temperature cycle (16 hours). An initial count of the percentage of germination was after four days and the final score was obtained on the seventh day of the experiment . 
The average value $(\mathrm{x})$, variance $\left(\sigma^{2}\right)$, and analysis of variance were computed. The analysis of variance was performed according to a randomised block design with two factors, allowing the calculation of the components of variance $(\sigma$ genetic, $\sigma_{\mathrm{gl}}^{2}$-interaction; $\sigma_{\mathrm{E}}^{2}$-environment; $\sigma_{\mathrm{f}}^{2}$-phenotypic), Falconer (1981). The significant differences among the average values were estimated according to the least significant difference (LSD) Hadživuković (1991).

\section{Weather conditions during the growing seasons}

During the study period, the values of temperature and precipitation were different between the two years of the experiment. The registered values of climatic parameters per experimental year were compared to the computed average values for the previous ten years (Table 1).

Table 1. Monthly and mean temperatures and monthly and cumulative precipitation

\begin{tabular}{|c|c|c|c|c|c|c|c|c|c|c|c|c|}
\hline $\begin{array}{c}\text { Temp } \\
\& \\
\text { Precip }\end{array}$ & Period & Oct & Nov & Dec & Jan & Feb & Mar & Apr & May & Jun & Xm & Total \\
\hline${ }^{0} \mathrm{C}$ & $2010 / 11$ & 9.2 & 11.1 & 2.7 & 0.3 & 0.6 & 6.6 & 12.2 & 15.6 & 20.4 & 8.74 & 78.7 \\
\hline${ }^{0} \mathrm{C}$ & $2011 / 12$ & 10.4 & 3.2 & 3.3 & -0.1 & -4.2 & 8.8 & 12.7 & 16.0 & 23.1 & 8.12 & 73.3 \\
\hline${ }^{0} \mathrm{C}$ & $2000 / 2010$ & 12.2 & 7.0 & 2.0 & 0.9 & 2.4 & 7.6 & 12.0 & 17.2 & 20.4 & 9.08 & 81.7 \\
\hline$(\mathrm{mm})$ & $2010 / 11$ & 93.6 & 34.1 & 64.9 & 28.1 & 59.2 & 48.9 & 37.1 & 82.9 & 71.7 & 57.8 & 520.5 \\
\hline$(\mathrm{mm})$ & $2011 / 12$ & 30.4 & 1.7 & 63.7 & $\begin{array}{c}107 . \\
1\end{array}$ & 54.9 & 24.5 & 69.1 & 105.5 & 17.8 & 52.7 & 474.7 \\
\hline$(\mathrm{mm})$ & $2000 / 2010$ & 64.3 & 57.4 & 48.5 & 42.8 & 44.7 & 52.5 & 66.6 & 74.9 & 92.2 & 60.4 & 543.8 \\
\hline
\end{tabular}

In the first year, the average temperature $\left(8.74^{\circ} \mathrm{C}\right)$ was similar to the ten-year average $\left(9.08^{\circ} \mathrm{C}\right)$, and in the second year, the average temperature $\left(8.12^{\circ} \mathrm{C}\right)$ was on average slightly lower than in the first year and than the ten year period. In the first year 2010/11, the amount of precipitation $(520.5 \mathrm{~mm})$ was higher than in the second year 2011/12 (474.7 $\mathrm{mm})$, but precipitation amounts in the first and second year were lower than the average amount of precipitation during the tenyear period $(543.8 \mathrm{~mm})$. The amount of precipitation in the first year was higher and favourable until the plant ripening stage in June. In the second year, the amount of precipitation during plant emergence (November) was extremely low, the distribution of precipitation from December to June was favourable at each stage of plant development, and precipitation amounts were low in June (17.8 $\mathrm{mm})$. These precipitation amounts were suitable for seed maturity, and were lower by $52.9 \mathrm{~mm}$ than in the first year and by $74.4 \mathrm{~mm}$ than the ten-year average. 


\section{Results and discussion}

The seed germination values of the barley cultivars were dependent on experimental year and nitrogen fertilisation treatment applied during the growing season. The obtained data indicate that all cultivars had higher values of seed germination in the second year than in the first year (Table 2). In the first year of the experiment, the highest average values of seed germination were found in the barley cultivar 'NS 589' (93.65\%), which had the highest average value of seed germination in all fertilisation treatments $\left(\mathrm{N}_{0}=0, \mathrm{~N}_{1}=20, \mathrm{~N}_{2}=40\right.$ and $\mathrm{N}_{3}=60 \mathrm{~kg}$ $\mathrm{ha}^{-1}$ ) except the control (without $\mathrm{N}$ ), in which the highest value of germination was found in the cultivar 'Jagodinac' (92.7\%). The lowest average seed germination was recorded in 'Premium' (92.16\%), which was the lowest value of seed germination in the control and in all treatments with different $\mathrm{N}$ application rates in the first experimental year.

However, 'Premium' had the highest average percentage of seed germination $(96.64 \%)$ in the second year of the investigation in all $\mathrm{N}$ fertilisation treatments and in the control. Also, this cultivar had the highest value of germination (98.0\%), which was found in $\mathrm{N}_{3}$ treatment during the two years of the experiment. The cultivar 'Jagodinac' had the lowest average percentage of seed germination $(94.70 \%)$ in the second year of the experiment as well in all $\mathrm{N}$ fertilisation treatments. In the control, the percentage of seed germination was lowest in 'NS-589' (93.8\%), which was slightly lower than in 'Jagodinac' (93.85\%).

All barley cultivars in both experimental years had the highest average percentage of seed germination $(94.7 \%)$ in the first year and $(97.21 \%)$ in the second year at the highest rate of nitrogen $\left(60 \mathrm{~kg} \mathrm{ha}^{-1}\right)$, while in the control treatment (without nitrogen) the lowest average seed germination was recorded in all cultivars $-91.5 \%$ in the first year and $94.15 \%$ in the second year (Table 2).

The average values of seed germination significantly differed among barley cultivars in the first and second experimental year (Tables 2 and 3). Also, the four cultivars showed significant differences in seed germination percentage between the first and the second year, and across treatments, indicating that weather conditions in the second experimental year favoured nitrogen uptake efficiency and that the rate of $\mathrm{N} 60 \mathrm{~kg} \mathrm{ha}^{-1}$ was most effective in promoting seed germination. However, seed germination increased on average with increasing $\mathrm{N}$ application rate in all barley cultivars in both years, indicating that nitrogen effect on seed germination is dependent on $\mathrm{N}$ application rate i.e. the effect of the environment $(81.87 \%)$ on the expression of germination percentage is greater than that of the genotype $(0.82 \%)$ (Table 3$)$. 
Table 2. Average percentage of seed germination in barley cultivars

\begin{tabular}{|c|c|c|c|c|}
\hline \multirow[t]{2}{*}{ Cultivars } & \multirow{2}{*}{$\begin{array}{l}\text { Nitrogen } \\
\mathrm{kg} \mathrm{ha}^{-1}\end{array}$} & \multicolumn{2}{|c|}{ Years } & \multirow{2}{*}{$\begin{array}{l}\text { Two-year } \\
\text { average }\end{array}$} \\
\hline & & $2010 / 11$ & $2011 / 12$ & \\
\hline \multirow[t]{5}{*}{ Jagodinac } & 0 & 92.7efg* & $93.8 \mathrm{f}$ & $93.3 \mathrm{fg}$ \\
\hline & 20 & $92.9 \mathrm{def}$ & $94.5 \mathrm{ef}$ & $93.7 \mathrm{ef}$ \\
\hline & 40 & 93.7cde & 94.9de & 94.4de \\
\hline & 60 & 94.4abc & $95.5 \mathrm{~d}$ & $95.0 \mathrm{~cd}$ \\
\hline & $\bar{x}$ & 93.4 & 94.7 & 94.1 \\
\hline \multirow[t]{5}{*}{ Premijum } & 0 & $90.1 \mathrm{i}$ & 95.1de & $92.6 \mathrm{~g}$ \\
\hline & 20 & $91.6 \mathrm{gh}$ & $96.6 \mathrm{c}$ & $94.1 \mathrm{e}$ \\
\hline & 40 & $93.0 \mathrm{~cd}$ & $96.8 \mathrm{bc}$ & $94.9 \mathrm{~cd}$ \\
\hline & 60 & $93.9 \mathrm{~cd}$ & $98.0 \mathrm{a}$ & $96.0 \mathrm{ab}$ \\
\hline & $\bar{x}$ & 92.2 & 96.6 & 94.4 \\
\hline \multirow[t]{5}{*}{ NS-589 } & 0 & 91.9fgh & $93.8 \mathrm{f}$ & $92.8 \mathrm{~g}$ \\
\hline & 20 & $91.9 \mathrm{fgh}$ & 95.0de & $94.0 \mathrm{ef}$ \\
\hline & 40 & 94.4abc & $96.4 \mathrm{c}$ & $95.4 \mathrm{bc}$ \\
\hline & 60 & $95.4 \mathrm{a}$ & $97.5 \mathrm{ab}$ & $96.4 \mathrm{a}$ \\
\hline & $\bar{x}$ & 93.6 & 95.7 & 94.7 \\
\hline \multirow[t]{5}{*}{ NS-595 } & 0 & $91.3 \mathrm{~h}$ & $93.9 f$ & $92.6 \mathrm{~g}$ \\
\hline & 20 & $92.8 \mathrm{def}$ & 95.0de & $93.9 \mathrm{ef}$ \\
\hline & 40 & $94.2 \mathrm{bc}$ & $96.3 \mathrm{c}$ & $95.3 b c$ \\
\hline & 60 & $95.2 \mathrm{ab}$ & $97.9 \mathrm{a}$ & $96.5 \mathrm{a}$ \\
\hline & $\bar{x}$ & 93.4 & 95.8 & 94.6 \\
\hline \multicolumn{5}{|c|}{ Average for nitrogen level } \\
\hline & 0 & 91.5 & 94.2 & 92.8 \\
\hline & 20 & 92.5 & 95.3 & 93.9 \\
\hline & 40 & 93.8 & 96.1 & 95.0 \\
\hline & 60 & 94.7 & 97.2 & 96.0 \\
\hline Total average & & 93.2 & 95.7 & 94.4 \\
\hline
\end{tabular}

* Values within columns with different superscripts are significantly different $(\mathrm{p} \leq 0.05)$

Table 3. Components of phenotypic variance for seed germination in barley cultivars

\begin{tabular}{|l|c|c|c|c|c|c|c|}
\hline \multirow{2}{*}{$\begin{array}{c}\text { Source of } \\
\text { variance }\end{array}$} & DF & MS & F-test & \multicolumn{2}{c|}{ LSD } & \multicolumn{2}{c|}{$\begin{array}{c}\text { Components of } \\
\text { variance }\end{array}$} \\
\cline { 5 - 9 } & & & & 0.05 & 0.01 & $\sigma^{2}$ & $\%$ \\
\hline Repetitions (R) & 3 & 0.618 & 2.5949 & - & - & - & - \\
\hline Genotypes (G) & 3 & 1.090 & $4.5788^{* *}$ & 0.5489 & 1.007 & 0.018 & 0.82 \\
\hline Nitrogen (N) & 3 & 29.488 & $123.8657^{* *}$ & 0.5489 & 1.007 & 1.793 & 81.87 \\
\hline Interaction(GxN) & 9 & 0.803 & $3.3716^{* *}$ & 0.7804 & 1.121 & 0.141 & 6.44 \\
\hline Error & 45 & 0.238 & - & - & - & 0.238 & 10.87 \\
\hline Total & 63 & - & - & - & - & 2.190 & 100.00 \\
\hline
\end{tabular}

** Significant at $\mathrm{p} \leq 0.01$ 
The analysis of variance showed significant differences in the percentage of seed germination across barley cultivars and $\mathrm{N}$ application rates in both years (Table 3). It also detected highly significant differences across genotypes (G), as well as between experimental years (Y), and in the genotype $\mathrm{x}$ year (GxY) interactions for the seed germination trait.

Seed germination is controlled by plant hormones, including abscisic acid (ABA), ethylene, gibberellins, auxin (IAA), cytokinins etc., which are involved in many physiological and biochemical processes in the plant. The balance between gibberellins and ABA determines seed germination ability or the pathways necessary for seed maturation (Miransari and Smith, 2014; Majidi et al., 2016). Reduced biosynthesis of gibberellins during seed germination is related to stress response (Colebrook et al., 2014). The functioning of connection gene hormones is related to germination response, which can be reduced under stress conditions (salt, drought) in sensitive barley cultivars (Emre et al., 2011; Thabet et al., 2018), and the physiological damage to the seed caused by stress can negatively affect seed viability and vigour, depending on genotype (Sun et al., 2007). In addition, the dynamic nature of root tip properties could have a significant impact on drought tolerance (Carter et al., 2019). Also, under salinity stress conditions, barley seed treatment with tryptophan and ascorbic acid as magneto-priming can improve seed germination (Hozayn and Ahmed, 2019).

\section{Conclusions}

Highly significant differences in seed germination were determined among barley cultivars, and the effect of mineral $\mathrm{N}$ fertilisation on the expression of the trait was established. For all cultivars, in both years, the lowest average values of seed germination were found in the control treatment (without N). In treatments with increasing rates of nitrogen, the percentage of germinated seeds increased in all cultivars. Averaged across cultivars, the highest percentage of germinated seeds was obtained at the highest nitrogen application rate in both years of the experiment. The barley cultivar 'Premium' had the lowest percentage of seed germination in the first year and the highest in the second year. The analysis of variance showed that nitrogen rate had a significant influence on the expression of percentage seed germination. The effect of nitrogen varies depending on environmental conditions in experimental years and on the genetic diversity of the investigated barley cultivars. In the expression of the percentage of germinated seeds, the effect of genetic factors was very low and the impact of environmental factors was highly significant. Interactions between genotypes, nitrogen application rates and years were also low. Germination percentage can be used as a marker for determining the capacity of barley plants to tolerate environmental stress and for predicting the adaptability of cultivars during germination and early seedling growth. 


\section{Acknowledgement}

This research was supported by the Ministry of Education, Science and Technological Development of the Republic of Serbia, Project TR 31092.

\section{References}

Carter A.Y., Ottman M.J., Curlango-Rivera G., Huskey D.A., Hawes M.C. (2019): Drought-tolerant barley:II. Root tip characteristics in emerging roots. Agronomy, 9: 220.

Chastain T.G., Ward K.J., Wysocki D.J. (1995): Seedbed residue and seed size relationships in winter barley. Agronomy Journal, 87 (3): 517-520.

Colebrook E., Thomas S., Phillips A., Hedden P. (2014): The role of gibberellin signaling in plant responses to abiotic stress. Journal of Experimental Biology, 217: 67-75.

Coventry S.J., McDonald G.K., Barr A.R., Eglington J.K. (2003): Genome locations influencing grain weight and size in Australian international mapping populations of barley (Hordeum vulgare L.). Australian Journal of Agricultural Research, 54:11031115.

Diaz-Mendoza M., Diaz I., Martinez M. (2019): Insight on the proteases involved in barley and wheat grain germination. International Journal og Molecular Sciences, 20 (9): 2087.

Emre Y., Feyza T., Cuneyt U., Filiz G. (2011): Physiological responses of elite barley (Hordeum vulgare L.) cultivars to salt stress at germination stage. Currnet Opinion in Biotechnology, 22: 150-152.

Falconer D.S. (1981): Introduction to quantitative genetics. Longwan, London and New York.

Hadživuković S. (1991): Statistički metodi. Drugo izdanje. "Radivoj Ćirpanov", Novi Sad.

Hozayn M., Ahmed A.A. (2019): Effect of magneto-priming by tryptophan and ascorbic acid on germination attributes of barley (Hordeum vulgare L.) under salinity stress. EurAsiana Journal of BioSciences, 13: 245-251.

ISTA Rules (2010): International Rules for Seed Testing. Int. Seed Testing Assoc., Switzerland.

Knežević D., Paunović, A., Madić, M., Djukić, N. (2007): Genetic analysis of nitrogen accumulation in four wheat cultivars and their hybrids. Cereal Research Communication, 35 (2): 633-636.

Knežević D., Milošević M., Torbica A., Broćić Z., Ćirić D. (2011): Variability of grain yield and quality of winter barley genotypes (Hordeum vulgare L.) under the influence of nitrogen nutrition. Növénytermelés suppl. 60: 25-28

Knežević D., Kondić D., Srdić S., Zečević V., Atanasijević S. (2015): Variability of grain mass per spike in winter barley cultivars (Hordeum vulgare L.) influenced by nitrogen nutrition. Növénytermeles, 64: 47-50.

Koutna K., Cerkal R., Zimolka J. (2003): Modification of crop management and its influence on the structure of yield and quality of spring barley grain. Plant Soil Envirnoment, 49 (10): 457-465. 
Kondić D., Knežević D., Paunović A. (2012): Grain weight of genotypes of triticale (X Triticosecale Wittmack) in agroecological conditions of Banja Luka. Genetika, 44 (2): 419- 428.

Kovačević V., Banaj D., Kovačević J., Lalić A., Jurković Z., Krizmanić M. (2006): Influences of liming on maize, sunflower and barley. Cereal Research Communication, 34 (1): 553-556.

Madić M., Paunović A., Knežević D., Zečević V. (2009): Grain yield and yield components of two-row winter barley cultivars and lines. Acta Agriculturae Serbica, $14(27): 17-22$.

Majidi M., Taghvaei M., Heidari G., Edalat M., Emam Y. (2016): Dormancy release of wild barley seed germination by using plant growth regulators. Environmental and Experimental Biology, 14:145-150.

Miransari M., Smith D.L. (2014): Plant hormones and seed germination. Environmental and Experimental Botany, 99: 110-121.

Moles A.T., Westoby M. (2006): Seed size and plant strategy across the whole life cycle. Oikos, 113: 91-105.

Monaco A. T., Mackown T.C., Johnson, A.D., Jones A.T., Norton M.J., Norton B.J., Redinbaugh G.M. (2003): Nitrogen effects on seed germination and seedling growth. Joutnal of Range Management, 56: 646-653.

Paunović A., Madić M., Knežević D., Bokan N. (2007): Sowing density and nitrogen fertilization influences on yield components of barley. Cereal Research Communication, 35 (2): 901-904.

Paunović A., Madić M., Knežević D., Jelić M., Djalović I. (2010): The effect of N fertilization and sowing density on the first-class grain contents in two-rowed spring barley. In Proceedings (ed. Z. Loncaric) 45th Croatian \& 5th International Sympposium Agriculture, Opatija: 874-877.

Ranieri B. D., Pezzini F.F., Garcia Q.S., Chautems A., França M.G.C. (2012): Testing the regeneration niche hypothesis with Gesneriaceae (tribe Sinningiae) in Brazil: Implications for the conservation of rare species. Australian Ecology, 37:125-133.

Silveira F.A.O., Negreiros D., Araújo L.M., Fernandes G.W. (2012): Does seed germination contribute to ecological breadth and geographic range? A test with sympatric Diplusodon (Lythraceae) species from rupestrian fields. Plant Species Biology, 27: 170-173.

Sun Q., Wang J., Sun B. (2007): Advances on seed vigor physiology and genetic mechanisms. Agricultural Sciences in China, 6: 1060-1066.

Thabet S.G., Moursi Y.S., Karam M.A., Graner A., Alqudah A.M. (2018): Genetic basis of drought tolerance during seed germination in barley. PLoS ONE, 13 (11): $\mathrm{e} 0206682$.

Yanlong H., Mantang W., Shujun W., Yanhui Z., Tao, M., Guozhen D. (2007): Seed size effect on seedling growth under different light conditions in the clonal herb Ligularia virgaurea in Qinghai-Tibet Plateau. Acta Ecologica Sinica, 27: 3091-3108.

Wang R., Chen B., Wang T., Li P., Ding F. (2019): Effect of chlorine dioxide on the germination, oxidative metabolism and growth of barley seedling (Hordeum vulgare L.). Scientific Reports. 8 www.nature.com/scientificreports.

Zečević V., Knežević D., Mićanović D., Urošević D. (2006): Influence of seed maturity on early seedling vigor in wheat. Kragujevac Journal of Science, 28 (1): 165-171. 